\title{
O PAPEL DAS PRÁTICAS JUDICIAIS NA PROMOÇÃO DA JUSTIÇA SOCIAL
}

http://dx.doi.org/10.21527/2176-6622.2021.55.188-203

Recebido em: 13/12/2019

Modificações solicitadas em: 6/8/2020

Aceito em: 7/9/2020

Luiz Sergio Fernandes de Souza

Pontifícia Universidade Católica de São Paulo - Faculdade de Direito. Rua Monte Alegre, 984 - 2o andar Perdizes. CEP 05014-901. São Paulo/SP, Brasil. http://lattes.cnpq.br/7685123874441725. https://orcid.org/0000-0003-3102-6353. luizsouza@tjsp.jus.br

\section{RESUMO}

O trabalho retoma uma reflexão corrente no campo da Sociologia e da Filosofia Jurídica brasileira, que se desenvolveu nas décadas de 70 a 90 na linha do funcionalismo e da teoria da ação social, consistente em saber de que forma o Direito e as práticas judiciais podem contribuir para mudanças sociais promotoras do bem-estar social e do igualitarismo, comprometidas com o respeito à dignidade das pessoas e com a tolerância. Não se trata de pesquisa empírica feita com base em levantamento de dados ou do exame da jurisprudência. Tampouco se cuida de investigação de ordem epistemológica, buscando-se apenas a análise de casos reveladores da natureza promocional do Direito. Na base do exame da legislação relativa a hipóteses de perda da propriedade pretende-se discutir práticas jurídicas emancipadoras. Analisa-se igualmente a possibilidade de revisão e até mesmo de resolução de contratos em razão de motivos ou fatos imprevisíveis. Regra de equidade também se faz presente quando se examina isenção tributária concedida a deficientes físicos, tanto quanto ao valorizar as práticas judiciais que levam à reparação do dano no âmbito dos Juizados criminais. No campo da improbidade administrativa também há lugar para o uso incremental do Direito, o que se dá na esfera da democracia participativa.

Palavras-chave: Mudança social. Direito e mudança. Desigualdade social. Direito promocional. Funcionalismo.

\section{THE ROLE OF JUDICIAL PRACTICES IN THE PROMOTION OF SOCIAL JUSTICE}

\section{ABSTRACT}

The work resumes a current reflection in the fields of Brazilian sociology and juridical philosophy, which developed from 1970 to 1990 along the lines of functionalism and the theory of social action, which consists in knowing how law and legal practices may contribute to social changes that not only promote social welfare and egalitarianism, but also are committed to respecting human dignity and to tolerance. This is not an empirical research based either on data collection or upon the examination of jurisprudence. Nor is this concerned with epistemological investigation, seeking only to examine cases which reveal the promotional nature of law. Based on the examination of the legislation connected to the hypothesis of property loss, we intend to discuss emancipatory legal practices. It is likewise discussed the possibility of reviewing and even of terminating contracts in the light of unpredictable reasons or facts. Equity rule is present when one examines tax exemption granted to disabled persons as well as in the valuation of the judicial practices which lead to damage reparation in criminal courts. In the field of administrative misconduct, there is also room for the incremental use of law. This happens in the ambit of participatory democracy.

Keywords: Social change. Law and change. Social inequality. Promotional law. Functionalism.

\section{SUMÁRIO}

1 Introdução. 20 direito como instrumento de mudança social. 3 Os instrumentos legais e a transformação social. 4 Direito, desigualdade social e democracia participativa. 5 Considerações finais. 6 Referências. 


\section{INTRODUÇÃO}

Pretende-se retomar, no presente trabalho, uma reflexão corrente no campo da Sociologia e da Filosofia Jurídica brasileira, nas décadas de 70 a 90, que teve curso, sobretudo na linha do funcionalismo e da teoria da ação social, em busca do reconhecimento do papel agregador do Direito na promoção de valores e comportamentos que importam para a coesão social.

Em outros termos, não basta identificar o caráter manipulador do Direito - como ocorre nas pesquisas que se desenvolvem sob a perspectiva do instrumentalismo jurídico - tampouco denunciar o caráter espoliador da superestrutura, instância em que o Direito se encontra na sociedade capitalista, segundo uma vulgata marxista. É preciso ir além, assumindo que o Direito, como saber prático, técnica de pacificação social, não é uma construção separada do agente, mas praxis na qual o sujeito que o aplica se reconhece como partícipe das relações sociais.

Cumpre advertir, contudo, que a pesquisa sobre a função social do Direito, nos limites do presente trabalho, não está voltada ao campo epistemológico - embora haja zonas de contato, por se estar tratando de um saber prático - mas sim à identificação, de um ponto de vista crítico (que incorpora contribuições do funcionalismo, da teoria da ação comunicativa e do marxismo humanista-emancipatório), dos diversos instrumentos jurídicos de promoção das camadas marginalizadas da sociedade brasileira, sobretudo nas grandes cidades.

A pesquisa, bem por isso, tampouco está orientada para uma crítica à "sobrejuridicização da sociedade como consequência da sobressocialização do Direito", na expressão de Castanheira Neves (1993, p. 61), a sugerir práticas de deslegalização, descriminalização e formas alternativas de Justiça. Não há absolutamente nenhuma objeção a estas concepções, ao discurso dos que defendem a necessidade da retração do Direito positivo, mas o enfoque aqui é outro, tratando-se de saber em que medida o ordenamento jurídico vigente, a depender da consciência moral e da consciência política, pode ser aplicado para promover ações sociais transformadoras.

Para a construção desse caminho, importante revela-se a interpretação histórico-cultural, rumo ao entendimento do sentido que a idealidade da norma ganha quando se confronta com a realidade social. A bem ver, a experiência jurídica - a vivência do direito imprescindível à apreensão do fenômeno jurídico na sua inteireza - não se faz sem a compreensão do fato social.

Desse viés, importam a pesquisa documental, o levantamento dos dados que permitem ao estudioso entender de que forma se faz o uso incremental do Direito. E a realidade por eles revelada aponta para um quadro de profunda desigualdade, que cabe ao operador retificar, corrigir, precisamente porque o Direito remete historicamente à noção de equidade, à justiça aplicada ao caso concreto, conforme a concepção aristotélica. É certo que o funcionalismo possibilita o entendimento e o controle da relação fato/norma, mas isto só não basta, cabendo às teorias discursivas do Direito dar ênfase ao seu caráter mobilizador, no que se põem de acordo com todas as correntes do humanismo.

\section{O DIREITO COMO INSTRUMENTO DE MUDANÇA SOCIAL}

A partir da Segunda Revolução Industrial - que ocorreu por volta de 1860, com a utilização da eletricidade e do petróleo como maiores fontes de energia - a sociedade tornou-se cada vez mais complexa, o que passou a exigir uma intervenção crescente do Estado para mediar conflitos que se dão no campo da justiça distributiva. Nesse contexto, mercê das ideias socialistas e comunistas, nascem os primeiros movimentos do operariado incipiente, as primeiras reivindicações por melhores condições de vida e trabalho, com o que o Direito codificado, que já vinha se descolando da tradição, vai se tornando lábil, mutável, diante da necessidade de se ajustar às novas demandas sociais.

O positivismo jurídico surge precisamente no contexto da perda das tradições, da exaltação do novo no lugar do sagrado, da racionalidade burocrática no lugar do costume, da multiplicidade de valores em vez de um sistema de valoração único e homogêneo, de um tempo em que se assiste ao eclipse da razão, para reproduzir a expressão de Horkheimer, que dá título a uma de suas obras.

É exatamente a realidade desse novo tempo - em que a esfera do econômico se especializa na base do surgimento da sociedade de classes, das ideologias no campo da estratificação social, do aparecimento de formas mais abstratas de propriedade, da família nuclear, da laicização, da transição demográfica (migração do 
meio rural para o urbano) - que passa a exigir um Direito transitório, maleável, posto por decisão, papel que o formalismo jurídico irá desempenhar plenamente, com a sua metodologia infensa à moral e aos supostos condicionamentos sociais do Direito (no que se afasta, a um só tempo, da tradição iluminista e do positivismo sociológico).

Tal qual se passa na esfera da Sociologia compreensiva de Max Weber (1969), o positivismo metodológico deixou-se impressionar pelo relativismo dos valores, mutáveis e temporais, passíveis de transformações, substituições e imbricações, o que exige um Direito constitutivo da realidade, expressão das razões do Estado, aproximando-se o positivismo jurídico da ideia de poder racional legal, um dos tipos concebidos por Weber, de fundamental importância para o entendimento do Direito no contexto das sociedades burocráticas.

O Direito da contemporaneidade, que se seguiu à Segunda Revolução Industrial, é precisamente aquele posto por decisão da autoridade, o que remete não só à ideia de um saber positivo que vai tomando o lugar da divindade e da tradição, fruto das relações capitalistas que conduzem à hegemonia do trabalho industrial, ao fenômeno da burocratização da sociedade e da política, como também a uma perda crescente da liberdade do indivíduo, liberdade que só existe a partir da norma.

Diante da necessidade de organização do consumo nas sociedades complexas - e especialmente nas sociedades do capitalismo tardio, como a brasileira - é preciso anular a dissensão, o que se faz não apenas na base dos aparelhos ideológicos do Estado, de que trata Marx (1965), a exemplo da polícia e da Justiça, mas também instaurando uma racionalidade formal, que opera a dispersão dos conflitos.

Essa violência simbólica, contudo, no limite, não consegue galvanizar as massas, havendo de se recorrer a outras formas de controle social para garantir a eficácia do sistema jurídico, a sua capacidade de absorção dos conflitos emergentes. Enfim, o Direito depende também de uma racionalidade material, que se põe no campo do uso competente da linguagem, do emprego da retórica, com vista à cooptação do endereçado da norma.

De fato, quanto maior a complexidade social, maior a incerteza, e quem domina a incerteza tem o poder. Até as recentes mudanças que se operaram no país, as quais se deram por força do crescimento disfuncional das cidades, com a especialização das atividades, a tercialização e a terceirização da economia - mudanças estas que encontraram no mundo digital um terreno fértil para expansão - a burocracia do Estado detinha esse poder de controle, colonizando inclusive o ambiente político.

Sucede que a representação política, aos poucos, foi perdendo o seu espaço de atuação para os grupos de pressão, que passaram a atuar não só na esfera do Legislativo e do Executivo, mas também no âmbito do Judiciário. Mais que isto, diferentemente daqueles que integram comissões de fábrica, sindicatos e entidades de classe, os grupos de pressão passaram a reclamar maior participação. Com isso, o discurso jurídico, que já havia se ajustado à lógica da luta corporativa (que não deixa também de ter o seu viés burocrático), teve de se adequar às reivindicações desses novos corpos intermediários da sociedade (ONGs, Organizações Sociais, terceiro setor, coletivos).

Como sustentam as teorias sistêmico-funcionalistas, todo sistema tende a uma entropia negativa. A questão consiste em saber como evitar esta implosão. Se é bem certo que esta pergunta demanda uma resposta conservacionista (e, nesta imediata , também conservadora, do ponto de vista político), é bem certo, igualmente, que estes novos movimentos sociais estão colocando à prova a capacidade de reinvenção do sistema, ao apontar suas insuficiências e contradições valorativas, o que, se de um lado pode bem ser contornado pela engenharia social, de outro é expressão de um alargamento do espaço de participação da sociedade no interior do Estado.

Trata-se, inegavelmente, de conquistas sociais, da ampliação de um espaço antes reservado a velhos segmentos da política, já açambarcados pela burocracia e pelas hostes do patrimonialismo. E quanto mais aqueles grupos marginais avançam, reivindicando a participação na condução da coisa pública, mais o sistema político e jurídico tem de ceder, porque já não funcionam mais as desgastadas estratégias da atomização dos conflitos e de dispersão do dissenso. Frutos desta pressão social, de uma certa internalização dos valores dissonantes por parte dos operadores do Direito, vão se operando transformações que não só refletem a necessidade de acomodação do sistema, como também a mudança de perspectiva. 
E como o Direito é uma ciência prática, a sua utilização incremental ou promocional também vai se incorporando aos complexos argumentativos que a chamada "teoria" jurídica produz. São novas práticas e novos paradigmas da dogmática analítica, influenciados por uma dogmática hermenêutica mais porosa no contato com o sistema social, o que permite decisões mais conformes aos novos padrões de civilidade, em que alteridade, diversidade, pluralismo, tolerância e respeito são faces do mesmo poliedro.

Desnecessário afirmar que esta construção tem a marca impressiva de toda a Sociologia que trata da relação entre Direito e mudança social, a exemplo dos escritos de Michel Crozier (1979), Mauro Cappelletti (1974), Wolfgang Friedmann (1966), David Trubek (1980), Simon Schwartzman (1982), Wanderley Guilherme dos Santos (1978), Niklas Luhmann (1983), Enzo Faletto e Fernando Henrique Cardoso (1970), Fernando Henrique Cardoso (1975), Lawrence Friedman e Jack Ladinsky (1980), Léon Duguit (1975), Talcott Parsons (1974), Fernando Ruivo (1989), Claus Offe (1981) e Norberto Bobbio (1980).

\section{OS INSTRUMENTOS LEGAIS E A TRANSFORMAÇÃO SOCIAL}

A chegada do século 21, com suas imagens sombrias e narrativas distópicas, faz pensar na importância de se retomar as reflexões em torno do caráter promocional do Direito. E a atuação agregadora da lei não se revela apenas nas finalidades perseguidas pelas legislações inovadoras, cada uma a seu tempo, a exemplo da Lei da Ação Popular, da Lei da Ação Civil Pública, da Lei de Responsabilidade Fiscal, da Lei de Improbidade Administrativa, da Lei de Investigação de Paternidade ou da Lei de Organizações Criminosas (que trouxe, entre outras medidas, a colaboração premiada e a ação controlada), tampouco em codificações e estatutos que representam verdadeiros marcos civilizatórios, a exemplo do Estatuto da Terra, do Estatuto da Criança e do Adolescente, do Código de Defesa do Consumidor e do Estatuto da Pessoa com Deficiência. ${ }^{1}$

Decerto, mesmo de regras legais bem mais antigas é possível extrair resultados que, a princípio, nem haviam sido perseguidos ou considerados pelo legislador, rumo à consecução da finalidade econômica e social da norma, o que permite entender a extensão do caráter incremental do Direito, a sua capacidade de promover não só valores que interferem na dignidade humana, como outros que, conquanto não sejam comuns a todos os homens, devem ser estimulados, sejam eles históricos, sejam eles também aglutinadores do ponto de vista da integração social.

Para dar um exemplo, veja-se a regra que trata da possibilidade de o poder público imitir-se provisoriamente na posse do imóvel objeto de decreto de desapropriação (artigo 15 do Decreto-Lei no 3.365, de 21/6/1941). Se for considerada a quantidade de prédios abandonados nas grandes cidades, e mais, a regra dos artigos 1으. III, da Constituição Federal (que consagra a dignidade da pessoa humana como um dos fundamentos da República Federativa do Brasil) e 3ㅇ, I e III (que diz ser objetivo primacial da República construir uma sociedade livre, justa e solidária, tanto quanto erradicar a pobreza, a marginalização e reduzir as desigualdades sociais), razoável se mostra a decretação de desapropriações daqueles imóveis, para atender à norma do artigo 5o, XXIII, da Constituição Federal (a propriedade atenderá a sua função social), com vista à criação de programas sociais de educação, moradia, creche, v.g.

De fato, a política de desenvolvimento urbano "tem por objetivo ordenar o pleno desenvolvimento das funções sociais da cidade e garantir o bem-estar de seus habitantes" (artigo 182). A ser assim, não se mostra razoável que prédios permaneçam abandonados por décadas, perturbando a vida de vizinhos e de moradores do entorno, além de deteriorar a paisagem urbana, bem comum de todos (artigo 225, caput, da CF). A sociedade não pode ficar à espera da resolução de desavença entre herdeiros, da extinção de falências, e o que é mais grave, à mercê da especulação imobiliária enquanto milhões de pessoas aguardam a instituição de programas sociais de saúde, o atendimento em creche, pré-escola e o desenvolvimento de políticas de Educação Fundamental, direito de todos e dever do Estado (artigos. 196, 205, 208, I, IV, e §1으, da CF).

A desapropriação de imóveis abandonados pelos donos, com vista ao desenvolvimento de programas habitacionais para a população de baixa renda, também é iniciativa que se impõe, pois a "propriedade urbana só cumpre sua função social quando atende às exigências fundamentais da ordenação da cidade expressas no

\footnotetext{
Na ordem em que os textos legais foram mencionados, fala-se aqui das Leis Federais no 4.717, de 29/6/1965; 7.347, de 24/7/1985; da Lei Federal Complementar no 101, de 4/5/2000; das Leis Federais no 8.429, de 2/6/1992; 8.560, de 29/12/1992; 12.850, de 2/8/2.013; 4.504, de 30/11/1964; 8.069, de 13/7/1990; 8.078, de 11/9/1990; 13.146, de 6/7/2015.
} 
plano diretor" (artigo 182, §2으, da CF), entre elas o direito à moradia (artigo 20, I, c.c. artigo 39, ambos do Estatuto da Cidade - Lei Federal no 10.257, de 10/7/2001) e o direito à utilização adequada dos imóveis urbanos (artigo 2ㅇ, Vl, $a$, da Lei Federal № 10.257, de 10/7/2001, e artigo 1.228, §1으, do Código Civil), cabendo acrescentar que compete ao município, também à vista da disposição do artigo 170, III, da Constituição Federal, promover o adequado ordenamento territorial, mediante planejamento e controle do uso, do parcelamento e da ocupação do solo urbano (artigo 30, VIII, da CF).

Aliás, a Constituição Federal, nos casos em que o solo urbano não é edificado, quando está subutilizado ou não utilizado, faculta ao poder público desapropriar o bem, pagando-o com títulos da dívida pública (artigo 182, §4으, III, da CF). Assim, decorridos cinco anos da cobrança do IPTU progressivo (artigo 70 da LF no 10.257, de 10/7/2001), sem que o proprietário tenha cumprido a obrigação de parcelamento, edificação ou utilização, o município poderá proceder à desapropriação do imóvel, com pagamento naquela forma (artigo 8o da LF no 10.257, de 10/7/2001). Admitindo-se que o poder público não queira seguir este caminho, bastará depositar o valor cadastral do imóvel (quase sempre muito abaixo do valor de mercado), imitindo-se imediatamente na posse provisória (artigo 15, §1으 do Decreto-lei no 3.365/41), com o que se verá em condições de dar à edificação uma destinação social, mediante pagamento da quantia finalmente arbitrada sob o regime do precatório.

Veja-se que, pondo de parte a previsão do Estatuto da Cidade, inspirada na regra do artigo 182, §4, III, da Constituição Federal, não se está cuidando, até aqui, de instrumentos legais recentes, mas de legislação concebida no ambiente do Estado Providência, cabendo observar que muito antes disto, sob a influência da noção de solidariedade, presente nas concepções de Émile Durkheim, Léon Duguit e François Gény - de perspectivas distintas, positivista e metafísica ${ }^{2}$ - o Código Civil de 1916 concebera a arrecadação do imóvel urbano abandonado, uma das causas de perda da propriedade (artigo 589, III, §2으, a, do Código Civil), que passava ao domínio do poder público contanto que tal situação perdurasse por dez anos. E, de fato, olhando desta forma, se já se operou a perda da propriedade, a indenização por meio da desapropriação não faz sentido. ${ }^{3}$.

Trata-se de legislação inspirada em princípios de justiça distributiva, cuja aplicação depende, todavia, de sensibilidade política e mobilização social em torno de valores que efetivamente importam, pois, para repetir John Rawls (1981, p. 191-201), diferenças somente se justificam se puderem favorecer aqueles que estão em posição menos privilegiada. Bastaria, contudo, realizar uma pesquisa in loco, fazendo um inventário dos imóveis abandonados há décadas pelo particular, para perceber que o Estado é leniente e perdulário, pois prefere tributar e autuar no âmbito do meio circulante - obtendo receita tributária e fazendo transferências correntes num universo de administrados perfeitamente identificável, com o que se vale do atributo da autoexecutoriedade de que está revestido o ato administrativo - a afetar à destinação pública aquilo que é de ninguém.

Ao se conduzir dessa forma, o poder público contribui para o estado de abandono das edificações, com o que também desampara as pessoas que mais precisam, renunciando a políticas públicas de inclusão social. Mais ainda, o poder público é um grande indutor do desequilíbrio ambiental, vale dizer, da poluição visual das grandes cidades, da ausência de áreas verdes e de condições sanitárias adequadas. Não são incomuns desapropriações feitas ao sabor dos interesses públicos de determinada época, sem um projeto mais consistente.

\footnotetext{
Partindo do conceito durkheimiano de solidariedade, Léon Duguit (1927) sustenta que ela está fundada no sentimento de sociabilidade e no sentimento de justiça, realidades recolhidas a partir da observação dos fatos. Para ele, a formulação de Durkheim é causalista, visto que, embora a norma social resulte do fato, assim como a biologia resulta do organismo vivo, certo é que os indivíduos, aos quais a primeira se aplica, têm consciência de seus atos. Além disso, a norma social cumpre uma finalidade. Léon Duguit entende também que os grupos sociais não são distintos das vontades individuais que os compõem. A crença na existência de uma vontade coletiva superior às consciências individuais, e a elas irredutível, só pode estar fundada em um princípio superior, em uma concepção metafísica. Assim, se o causalismo, por um lado, desconsidera a evidente diferença entre fatos sociais e fatos físicos, a crença em uma vontade sobrenatural, por sua vez, desconsidera valores que cada indivíduo. Para François Gény - cujas críticas foram expostas pelo próprio Léon Duguit, em seu Tratado - a noção de "sentimento de sociabilidade" e de "sentimento de justiça" é um conceito a priori, que recorre aos princípios superiores da razão pura, com o que se garante a passagem do fato à norma. Na visão de Gény, as elaborações de Duguit têm o mesmo viés metafísico por este identificado na concepção de solidariedade, desenvolvida por Durkheim.

3 Atualmente, a perda do imóvel por abandono é regulada na norma dos artigos 1.275, III, e 1.276 do Código Civil (Lei Federal no 10.406, de 10/1/2002), que diminuiu o prazo de dez anos, após o qual o imóvel abandonado pode ser arrecadado como bem vago, para três anos, contemplando, também, uma nova modalidade de perda de propriedade imóvel, que se dá quando o dono deixa de exercer a posse sobre o bem e, ao mesmo tempo, deixa de pagar os tributos incidentes sobre a respectiva propriedade, hipótese em que se opera a presunção absoluta de abandono (artigo 1.276, §2ำ do CC). Os mais aferrados a uma concepção individualista da propriedade defendem que se trata de regra inconstitucional, por ferir o devido processo legal, por caracterizar confisco e por investir contra o princípio da razoabilidade (FARIAS, 2009).
} 
Nesse contexto, o poder público acaba desapropriando sem maior critério, com o que tem de indenizar, por força do chamado direito de extensão (artigo 12 do Dec. no 4.956, de 9/9/1903), o remanescente da área expropriada, que depois resta abandonado. Às vezes desapropria e não executa o projeto, o que dá direito à retrocessão (artigo 519 do CC e artigo 35 do Decreto-lei no 3.365, de 21/6/1941).

Sob o ponto de vista das relações contratuais, o Código Civil de 2002, seguindo as pegadas do Código de Defesa do Consumidor, tratou de colocar a salvo a situação subjetiva daqueles que, muito embora não estivessem sob a pressão da sociedade de consumo, submetidos à lógica de mercado, revelavam-se, em determinadas circunstâncias, carecedores de amparo jurídico específico, porque fragilizados.

De fato, acha-se em situação de vulnerabilidade aquele que se torna presa da alteração anormal das circunstâncias em que contratou a locação de um imóvel, por exemplo, a realização de um trabalho (empreitada) ou uma compra e venda, inspirando-se o Código Civil na norma do artigo 6o, V, da Lei Federal no 8.078, de 11/9/1990, dispositivo que garante a revisão das cláusulas contratuais em razão de fatos supervenientes que as tornem excessivamente onerosas.

Daí a razão de ser da norma do artigo 317 do Código Civil ("Quando, por motivos imprevisíveis, sobrevier desproporção manifesta entre o valor da prestação devida e o do momento de sua execução, poderá o juiz corrigi-lo, a pedido da parte, de modo que assegure, quanto possível, o valor real da prestação"), da regra do artigo 478 ("Nos contratos de execução continuada ou diferida, se a prestação de uma das partes se tornar excessivamente onerosa, com extrema vantagem para a outra, em virtude de acontecimentos extraordinários e imprevisíveis, poderá o devedor pedir a resolução do contrato") e da disposição do artigo 480 ("Se no contrato as obrigações couberem a apenas uma das partes, poderá ela pleitear que a sua prestação seja reduzida, ou alterado o modo de executá-la, a fim de evitar a onerosidade excessiva"), os dois últimos artigos de lei tratando, precisamente, da resolução do contrato por onerosidade excessiva, e o primeiro deles a demandar a atuação do juiz, na base dos preceitos de equidade, para restabelecer o sentido da justiça comutativa.

De particular interesse, nos casos de alteração dos termos do contrato resultante de fato superveniente, é a noção de imprevisibilidade, contida na regra do já citado artigo 317 do Código Civil, havendo de se entender, à vista da situação de vulnerabilidade em que se acham as pessoas mais simples, que não se pode tomar de empréstimo o critério do "homem médio", levando em conta, isto sim, o critério subjetivo, que considera as condições pessoais do agente, sua capacidade cognitiva diante das limitações que lhe são próprias e das condições em que atuava. ${ }^{4}$ Afinal, a tese formulada por Ortega y Gasset nos seus primeiros escritos, "Yo soy yo y mi circunstancia" (1983, p. 322), já indica que o conhecimento, ainda que racional, está enraizado na vida.

Pode impressionar o fato de se recorrer à esfera do Direito Penal a fim de retirar de um dos elementos do conceito de "culpa", para aplicação à teoria dos contratos, o entendimento do que venha ser "imprevisível", expressão utilizada nos artigos 317 e 478, ambos do Código Civil, fazendo-o não para se referir ao estado de espírito do agente ("fato imprevisto"), mas sua condição, do ponto de vista cognitivo, de prever o fato. É que a dogmática civil não se ocupa da definição. De mais a mais, trata-se de categoria que se inscreve entre os conceitos básicos do Direito, vale dizer, no campo da teoria geral do Direito (NINO, 1984).

A tese aqui defendida, no sentido de que se deva considerar, na aferição da capacidade de prever as consequências do ato jurídico praticado, as condições pessoais do contratante, tem em conta o caráter incremental do Direito, a necessidade de se proceder a uma interpretação emancipadora da legislação vigente. ${ }^{5} \mathrm{E}$, nesta medida, a intervenção do Judiciário, longe de se inscrever no campo da simples correção da comutatividade (synallagmata), põe-se na esfera da justiça social, conceito que já se encontrava em Platão, como se retira da referência à solidariedade, tanto quanto em Aristóteles, como se vê nas noções de justiça geral e justiça legal, ambas voltadas à consecução do bem comum.

Decerto, quando o magistrado intervém na relação contratual, diante de fato superveniente, para restabelecer o equilíbrio rompido, importa considerar, muito além do caráter particular comutativo em que interfere sua atuação institucional, o papel de guardião da Justiça representado pelo juiz, que neste sentido também

\footnotetext{
4 A propósito dos critérios objetivos e subjetivos de aferição da previsibilidade (que se acham no exame da culpa), ver: MANZINI (1948, p. 693-695) e (ZAFFARONI, 1981, p. 408-413).

${ }^{5}$ Em sentido diferente, defendendo a adoção de um critério objetivo para o exame do conceito de imprevisibilidade, ver: ASCENSÃO (2009, p. 170).
} 


\section{Debate}

é o guardião da igualdade (ARISTÓTELES, 1967). Outra não é a dimensão da solidariedade em Platão (1969), como se colhe na advertência segundo a qual cada um deve desempenhar na polis a função que lhe cabe, aquilo que a comunidade dele espera, incumbindo a todos aceitar essa divisão de funções políticas, o que inclui a prestação da justiça. Esta é a justiça social em Platão (BRÉHIER, 1988).

Como reconhecem os filósofos do Direito, toda ação ordenada ao bem comum, à consecução das finalidades sociais do Direito, participa do conceito de justiça social (MONTORO, 1991), de sorte que não será o fato de o juiz atuar no restabelecimento do equilíbrio contratual entre particulares (sobretudo quando um deles é hipossuficiente) razão suficiente para negar a existência, nessa atividade, de uma ação social (no sentido da retórica aristotélica), capaz de recompor a relação de igualdade.

Aliás, esse sentido equitativo da justiça social influenciou toda a construção do humanismo cristão, que incorporou, precisamente, a metafísica do platonismo e do aristotelismo. A doutrina social da Igreja, contida na Rerum Novarum, um dos textos sociais mais célebres da História Moderna, tratando particularmente dos trabalhadores, é um convite à ação social, que se faz na base do reconhecimento da dignidade humana e da necessidade de atender o bem comum (LEÃO XIII, 1950).

E desde a Segunda Revolução Industrial, período em que se inscreve a Encíclica, a condição da gente humilde vem passando por um crescente processo de deterioração social, mercê da intensificação das relações de consumo, do aumento da concentração do capital e da automação do trabalho. A ideia de exclusão social remete precisamente "ao conjunto de dificuldades, dos modos e dos problemas de uma inclusão instável e precária (...) daqueles que estão sendo alcançados pela nova desigualdade social produzida pelas grandes transformações econômicas", pessoas "para as quais não há na sociedade senão lugares residuais" (MARTINS, 1997, p. 28-29).

Para a lógica capitalista é impossível expandir e crescer sem mercado, sem compradores, sem incluídos, somente com excluídos, que são fruto dela própria. Como adverte José de Souza Martins, a sociedade capitalista exclui para depois incluir de outro modo, segundo suas próprias regras, com o que se opera a inclusão do ponto de vista econômico e a exclusão do ponto de vista social e moral (MARTINS, 1997).

O processo de mecanização da produção e da informatização do consumo redefine a posição das pessoas no mundo do trabalho e as condições de fruir os bens e utilidades, o que explica a situação de pleno emprego à custa de salários miseráveis e o crédito fácil a juros escorchantes, combinação que conspira contra o gozo das liberdades públicas, aí incluídas as liberdades econômicas fundamentais previstas no Pacto Internacional de Direitos Econômicos, Sociais e Culturais, adotado pela Resolução no 2.200A (XXI) da Assembleia Geral das Nações Unidas, de 16/12/1966, e aprovado pelo Brasil por meio do Decreto Legislativo no 226, de 12/12/1991, e pelo Decreto Executivo no 591, de julho de 1992.

No mesmo sentido, e pelas mesmas razões, entende-se que o conceito de "onerosidade excessiva", de que trata a regra do artigo 480 do Código Civil, se presente a situação de vulnerabilidade da parte que se obrigou no contrato unilateral, há de ser interpretado de maneira elástica, em nada desautorizando esta afirmação as alterações que a Lei Federal no 13.874, de 20/9/2019, promoveu no Código Civil, mormente porque o hipossuficiente, no mais das vezes, recebe o instrumento de contrato pronto para assinar (artigo 113, §1으, IV, do (C). Anote-se ainda que os princípios da boa-fé, da proporcionalidade e da racionalidade econômica (artigo 113, §1으, III e V, do CC) já se achavam inscritos na Parte Geral do texto de 2002 (artigo 187).

Com isto, recompõe-se o equilíbrio contratual, cabendo lembrar que "A liberdade de contratar será exercida nos limites da função social do contrato" (artigo 421 do CC), regra inspiradora da norma do artigo 156 do Código Civil ("Configura-se o estado de perigo quando alguém, premido da necessidade de salvar-se, ou a pessoa de sua família, de grave dano conhecido pela outra parte, assume obrigação excessivamente onerosa"), do artigo 157 ("Ocorre a lesão quando uma pessoa, sob premente necessidade, ou por inexperiência, se obriga à prestação manifestamente desproporcional ao valor da prestação oposta.-\$1으 Aprecia-se a desproporção das prestações segundo os valores vigentes ao tempo em que foi celebrado o negócio jurídico") e do artigo 413 ("A penalidade deve ser reduzida equitativamente pelo juiz se a obrigação principal tiver sido cumprida em parte, ou se o montante da penalidade for manifestamente excessivo, tendo-se em vista a natureza e a finalidade do negócio"). Neste contexto há de ser interpretada a norma do parágrafo único do artigo 421, introduzida pela Lei Federal no 13.874, de 20/9/2019. 
Enfim, conquanto se esteja no campo das relações privadas, é bem de ver que o Código Civil de 2002, ao que se retira de uma exegese sistemática, sinalizou no sentido de uma compreensão mais ampla da cláusula rebus sic stantibus, tanto assim que o legislador classifica como ilícito o ato de quem, a pretexto de exercer o Direito, excede manifestamente "os limites impostos pelo seu fim econômico ou social" (artigo 187). E a presunção relativa estabelecida na norma do artigo 421-A, também introduzida pela Lei Federal no 13.874, de 20/9/2019, não conspira contra esta conclusão, pois nada mais "concreto" e ostensivo que a pobreza e a riqueza, uma indispensável à outra, no dizer de Anatole France ${ }^{6}(1922$, p. 232), o que de resto satisfaz o espírito consequencialista da norma do artigo 113, §1ㅇ do Código Civil.

Na interseção entre a responsabilidade civil e a responsabilidade penal também há espaço para uma interpretação emancipadora do Direito que, infelizmente, quer por uma certa acomodação, quer por falta de condições materiais, não se vem fazendo nos tribunais. Se é bem certo que, apesar das possibilidades que estão postas para o administrador, no terreno da desapropriação, existe um déficit na atuação promocional do Direito, é inegável que o fato se verifica, da mesma forma, no que concerne à aplicação da regra dos artigos 72, 74, 75, 79 e 89, I, todos da Lei Federal no 9.099, de 26/9/1995, por parte do poder Judiciário, déficit jurisdicional que prejudica sobretudo as pessoas mais humildes.

Cabe ressaltar que pessoas acidentadas muitas vezes não contam com uma rede de proteção social para vencer as dificuldades econômicas enfrentadas no período de convalescença, situação que tenderia a se agravar com a extinção do "seguro obrigatório de danos pessoais causados por veículos automotores de via terrestre, ou por sua carga, a pessoas transportadas ou não", regulado pela Lei Federal no 6.194, de 19/12/1974, extinção esta que se deu por meio da Medida Provisória no 904, de 11/11/2019, não fosse a atuação do Supremo Tribunal Federal que, cautelarmente, suspendeu os efeitos daquela Medida Provisória.

O Código de Processo Civil prevê a possibilidade de execução civil da sentença penal condenatória contanto que ela tenha estabelecido o valor da indenização, admitindo-se, também, a prévia liquidação (artigos 515, VI, §1으, do CPC). Tudo isto, no entanto, exige muito tempo. A Lei Federal no 9.099, de 26/9/1995, fiel a seu espírito de racionalização, buscou dar maior eficiência a esta intercomunicação das esferas civil e criminal. Para tanto, sinalizou com a possibilidade de o autor do dano indenizar a vítima, obtendo, como uma espécie de sanção premial, a homologação do acordo, o que o livra de ser processado (artigos. 72 e 74 da Lei Federal no 9.099, de 26/9/1995). Nova oportunidade de obter do ofensor a reparação do dano surge durante a instrução do processo, com a chamada transação penal (artigos 78 e 79) ou, então, ainda no momento em que a denúncia é oferecida, hipótese na qual, satisfeitos outros requisitos legais, o processo fica suspenso no aguardo do cumprimento das condições impostas (artigo 89).

Na prática, diante da simples alegação do autor do fato de que não reúne recursos para indenizar a vítima, sem que se recorra aos meios suasórios presentes em qualquer tentativa de conciliação ou composição, instaura-se a relação processual penal, ou nela se prossegue até a prolação de sentença, perdendo-se, assim, excelente oportunidade de desafogar a máquina judicial e ao mesmo tempo promover justiça com eficiência, presteza e resultado econômico imediato, para milhares de jurisdicionados, em sua grande parte vítimas de acidente de trânsito.

No campo das relações tributárias e no âmbito do poder Judiciário, há iniciativas que investem na promoção de valores socialmente importantes. Trata-se de julgados que garantem a isenção do IPVA e do ICMS tanto ao deficiente físico condutor quanto ao deficiente físico não condutor, na base de interpretação que desvincula o favor fiscal da necessidade de adaptação do veículo, cujos gastos, segundo a regra do artigo 19 (Anexo I) do Decreto Estadual no 45.490, de 30 de novembro de 2000, no que diz respeito ao ICMS, e a norma do artigo 13, III, da Lei Estadual no 13.296, de 23 de dezembro de 2008, no que se refere ao IPVA, justificariam a isenção. De acordo com os fundamentos dos referidos acórdãos, não faria sentido que a determinado deficiente físico, portador de discretas limitações de deambulação, em condições de dirigir um automóvel adaptado, fosse concedida a isenção, e a outro, tetraplégico, por exemplo, não se a concedesse, pois este, ainda que conduzido por terceiro, retiraria proveito da isenção (7ạ Câmara de Direito Público do TJSP, Apelação Cível no 0009241-55.2011.8.26.0602, v.u., j. 4/6/2012). À vista disto, o poder Executivo entendeu por bem garantir

\footnotetext{
Aqui o escritor francês, cuja ironia faz lembrar o estilo de Voltaire, lança um áspero e espirituoso panfleto contra a magistratura, dura com os pequenos, indulgente com os poderosos.
} 


\section{Debate}

a isenção para deficiente condutor e deficiente não condutor, o que se deu por meio do Decreto Estadual no 58.897, de 20 de fevereiro de 2013, no caso do ICMS, e na base da Lei Estadual no 16.498, de 18 de julho de 2017, no que diz respeito ao IPVA.

Ainda a propósito da isenção de IPVA para deficientes físicos, a Fazenda do Estado de São Paulo, com base na nova redação do artigo 13 da Lei do IPVA paulista, que se operou por meio do artigo 40, I, da Lei Estadual no 16.498, de 18 de julho de 2017, passou a dispor acerca do valor máximo do veículo objeto da isenção, levando o deficiente, caso quisesse usufruir do benefício fiscal, a se desfazer do automotor, com vista à aquisição de outro de valor mais baixo. Sucede que, ao fazê-lo, o contribuinte acabava por perder a isenção de IPI, pois a Lei Federal no 8.989, de 24 de fevereiro de 1995, condiciona a subsistência deste favor fiscal à permanência da condição de proprietário do veículo pelo período de dois anos. Decidiu o Tribunal de Justiça de São Paulo que não seria razoável, à vista da regra do artigo 111 da Constituição do Estado ("A administração pública direta, indireta ou fundacional, de qualquer dos poderes do Estado, obedecerá aos princípios de legalidade, impessoalidade, moralidade, publicidade, razoabilidade, finalidade, motivação e interesse público"), que a Administração Tributária instaurasse uma situação de verdadeiro impasse, deixando o contribuinte em posição insustentável (7ạ Câmara de Direito Público, Apelação Cível no 1008486-95.2018.8.26.0625, v.u., j. 25/4/2019).

\section{DIREITO, DESIGUALDADE SOCIAL E DEMOCRACIA PARTICIPATIVA}

O ordenamento jurídico vigente oferece importantes instrumentos de ação social para promover o bem-estar dos administrados, bastando, muitas vezes, certa inventiva, certa criatividade, que andam a par com aquilo que se conhece como vontade política. No mais das vezes esses instrumentos legais, ao invés de atuarem de maneira agregadora, do ponto de vista social, são utilizados de maneira disfuncional, como se viu nas situações em que o imóvel é desapropriado, com o pagamento do preço pelo poder público, permanecendo ao abandono. Uma pesquisa de campo nas principais cidades do país - a julgar pelos dados empíricos de que se dispõe, na base de notícias da imprensa - confirmaria a tese de que o poder público utiliza muito mal os instrumentos jurídicos existentes para elevar a qualidade de vida dos brasileiros.

Em países do capitalismo tardio, como o nosso, as pressões demográficas atuam de maneira mais acelerada do que nos países desenvolvidos. Mais que isso, o Brasil envelheceu sem estabelecer uma política de transferência de renda adequada, passando da condição de uma sociedade jovem e rural para uma configuração urbana com um ciclo de vida maior. Com isso, crescem as demandas por alimentos e bens de consumo, desafiando o emprego de novas tecnologias devido à escassa produção de riqueza. As novas tecnologias exigem, por sua vez, mão de obra qualificada.

Ocorre que o país tem 54 milhões de pessoas sem instrução ou com nível fundamental incompleto, segundo o Censo Demográfico de 2010 realizado pelo IBGE. De acordo com a Pesquisa Nacional por Amostra de Domicílio (Pnad) Contínua, relativa ao segundo trimestre de 2019 , realizada por aquele mesmo Instituto, os jovens de 18 a 27 anos são os maiores atingidos pela falta de trabalho, somando 5,15 milhões de desempregados contra 17,7 milhões de empregados nesta mesma faixa etária, o que representa 10,5 pontos percentuais acima da taxa de desemprego verificada entre a população de todas as idades ${ }^{7}$ (O DRAMA..., 2019).

"Mesmo após o fim da recessão econômica, o país registrou, em 2018, o recorde de 13,537 milhões de pessoas vivendo na miséria, contingente maior do que toda a população da Bolívia. Os dados são da pesquisa Síntese de Indicadores Sociais (SIS)", de 2018, também divulgada pelo IBGE. A extrema pobreza (ou seja, situação daqueles que vivem com rendimentos inferiores a US\$1,90 por dia, segundo classificação do Banco Mundial) cresceu nos últimos anos em decorrência da "deterioração do mercado de trabalho, que prejudicou especialmente trabalhadores com menos escolaridade", o que exige políticas públicas de distribuição de ren-

Douglas Gravas (2019) registra que aumenta o número de graduados em universidades que ganham um salário mínimo ou menos, segundo dados da última Pesquisa Nacional por Amostra de Domicílios (Pnad) Contínua, realizada pelo IBGE, precarização das relações de trabalho que aponta para a remuneração de menos de $\mathrm{R} \$ 5,00$ por hora de um terço do total de trabalhadores. Segundo mostra um estudo inédito do Instituto de Economia da Fundação Getúlio Vargas, o país tem hoje 38,8 milhões de pessoas no mercado informal de trabalho. "Pagar um salário menor é uma característica típica de ocupações pouco produtivas", a exemplo dos "entregadores de aplicativos" e vendedores ambulantes. Os dados da pesquisa da FGV integram a reportagem de Vinícius Nader (2019). 
da mais eficientes. O aumento do número de miseráveis no país (eram 4,5\% abaixo da linha de pobreza em 2014, passando em 2018 para 6,5\%) também reclama políticas públicas de inclusão produtiva e programas assistenciais de amparo à população mais pobre ${ }^{8}$ (AMORIM; NADER, 2019).

Enfim, em alguns rincões do país não se fez nem a Revolução Francesa. ${ }^{9}$ A quinta parte da pirâmide socioeconômica, os que estão na base dela, ganham $18 \%$ da renda média nacional, segundo pesquisa realizada pela Fundação Getúlio Vargas, encontrando-se um pouco acima do rendimento de Uganda (um dos países mais pobres do mundo), que é de 15\%: são 42 milhões de brasileiros. ${ }^{10}$ Nas Regiões Norte e Nordeste do país são 74.156 milhões de brasileiros sem acesso à coleta de esgoto sanitário (35,7\% da população total), segundo dados da pesquisa Síntese de Indicadores Sociais (SIS), de 2.018, o que acaba onerando o serviço público de saúde (AMORIM; NADER, 2019).

Há centenas de cientistas que realizam pesquisa no campo da pobreza globalizada, cabendo lembrar os economistas Abhijit Banerjee, Esther Duflo e Michael Kremer, que ganharam recentemente o Prêmio Nobel de Economia pelos experimentos realizados visando a atenuar a pobreza num amplo espectro de segmentos, os dois primeiros estudiosos, especificamente, com interesse na avaliação de políticas públicas de combate à pobreza.

No presente trabalho não se busca desenvolver propriamente uma pesquisa de campo, mas uma investigação normativo-dogmática e empírica na tentativa de reconhecer a possibilidade de um Direito promocional a partir dos instrumentos legislativos existentes no ordenamento jurídico nacional, prática que se desenvolve na base de uma interpretação emancipadora do Direito vigente.

Dados empíricos autorizam afirmar que o poder público elege mal as suas prioridades, não se podendo pôr de lado ainda a circunstância de que as más escolhas estão enredadas, em muitos casos, por práticas patrimonialistas, interesses velados e condutas ímprobas. Mesmo as escolhas certas, muitas vezes, soçobram por falta de cumprimento de metas, o que envolve basicamente a execução de orçamento, peça que contém aspectos operativos (orçamento anual) e programáticos (orçamento plurianual).

O Tribunal de Contas do Estado de São Paulo, na base de levantamento feito por auditores, com dados coletados até setembro de 2019, apurou que o número de obras públicas paralisadas ou atrasadas no território paulista, de responsabilidade do governo estadual e dos governos municipais, soma investimentos da ordem de $\mathrm{R} \$$ 49.644.569.322,13, em diversas áreas como educação, saúde, habitação, segurança e mobilidade urbana (TCE..., 2019). Isto faz pensar nos vários instrumentos jurídicos de participação democrática na gestão da coisa pública, fruto da elaboração legislativa que se fez no período de redemocratização do Estado brasileiro.

No dizer de Moreira Neto (2007, p. 251-271), a coleta de opinião, o debate público e a audiência pública - processos de participação na administração pública abertos a grupos sociais determinados, identificados por certos interesses coletivos ou difusos, visando a legitimar a ação administrativa pertinente a tais interesses - encontram ampla previsão constitucional (artigos 29, XII, 37, §3으, 58, § 2ㅇ, II, 194, VII, 198, III, 204, II, 225, caput, da CF) e infraconstitucional (artigo 39, caput, da LF no 8.666, de 21/6/1993, artigos. 31 a 34 da LF no 9.784, de 29/01/1999, artigo 3ㅇd da LF no 8.897, de 23/01/1999, e artigos. 2ㅇ, II, e XIII, 40, III, f, 43, II e IV, estes da LF no 10.257, de 10/7/2001). Trata-se de uma forma de organização do consenso, de legitimação das decisões que encontra seu lugar na noção de democracia ética.

De fato, na formulação da ideia de Estado Democrático de Direito - regime adotado no Brasil, no qual se inscrevem não só a vontade da maioria, a igualdade e a liberdade, mas também a garantia dos direitos das minorias, o pluralismo político, o respeito à dignidade, ao trabalho e à livre iniciativa (artigo 10, incisos e parágrafo único, da CF) - importa a construção de um sujeito consciente de suas possibilidades e de seus limites em relação aos outros, o que se inscreve na esfera da democracia ética.

\footnotetext{
8 O economista Pedro Fernando Nery (2019a), reportando-se também à Síntese de Indicadores Sociais (SIS), de 2018, publicada pelo IBGE em novembro de 2019 , aponta que mais de $40 \%$ das crianças brasileiras vivem abaixo da linha da pobreza.

9 Rousseau, nos discursos apresentados na Academia de Dijon, faz uma vigorosa crítica à civilização burguesa e às desigualdades por ela engendradas ( $A$ origem da desigualdade entre os homens. Tradução de Eduardo Brandão. São Paulo: Pinguim \& Cia das Letras, 2017).

${ }^{10}$ A propósito, veja-se a matéria intitulada "Uganda, aqui", de Pedro Fernando Nery (2019b).
} 
O direito de participar da condução da coisa pública, inscrito na regra do artigo XXI da Declaração Universal dos Direitos Humanos (1948), ganha aqui novos contornos, pois não se trata apenas da prerrogativa de votar e disputar eleições, mas sim de um envolvimento com a gestão da coisa pública, interpretação consentânea com a norma do artigo 10 da Constituição Federal ("Todo o poder emana do povo, que o exerce por meio de representantes eleitos ou diretamente"). Bem por isto, o status libertatis e o status civitatis decorrem não só das ações tradicionais no campo da política, como também da instituição e preservação de um espaço democrático de discussão e controle social, o que se faz por meio da criação e funcionamento de conselhos consultivos e deliberativos no qual atuam representantes de diversos setores da sociedade. ${ }^{11}$

Não por acaso, a Suprema Corte, recentemente, provocada a se manifestar sobre o Decreto Presidencial no 9.759/19, que extinguia todos os conselhos, comitês, grupos e comissões, atuantes na esfera da administração federal, que não tivessem detalhamento das suas atribuições e composição, concedeu a liminar para impedir essa indevida interferência do chefe do Executivo, com limitação do alcance do Decreto, no aguardo do julgamento da ação constitucional (ADIn no 6.121-DF).

A ideia de democracia ética também encontra-se presente na previsão do artigo 4으, $V, r$, da Lei Federal no 10.257, de 10/7/2001, que, tratando dos instrumentos jurídicos da política urbana, contemplou o direito à assistência técnica e jurídica gratuita em favor das comunidades e grupos sociais menos favorecidos, o que dá voz a segmentos da sociedade cuja opinião nem sempre é levada na devida consideração, pela falta do chamado "discurso competente". Cresce, neste âmbito, a importância das Defensorias Públicas (artigo 134, e parágrafos, da Constituição Federal).

Em outras palavras, a praxis do Direito revela-se não só na interpretação que os tribunais dão a leis e normas em geral, rumo à realização dos valores constitucionais que consagram a dignidade da pessoa humana, a construção de uma sociedade livre, justa e solidária, comprometida com a erradicação da pobreza, da marginalização e com a redução das desigualdades, como também na orientação jurídica e defesa dos necessitados, direito elevado à condição de garantia constitucional (artigo 5ㅇ, LXXIV, da CF). Cumpre lembrar, nessa medida, que se ao juiz só é dado agir quando provocado, por força do princípio dispositivo (artigo 2 으, do CPC), certo é que a construção da justiça é dialógica, e também participativa (artigos. 60 e 357, $\S 10$, do $\mathrm{CPC}$ ).

Ainda na esfera da assistência jurídica, mas pensando agora no controle eficiente da administração pública, mostra-se importante investir na criação de carreiras jurídicas da advocacia do município, reconhecendo que os procuradores municipais, no trabalho de consultoria e assessoramento jurídico do poder Executivo - sem prejuízo da assistência jurídica que a Procuradoria Geral do Estado também presta aos municípios em alguns Estados Federados, a exemplo de São Paulo (artigo 99, VIII, da CE) - são peças-chave para o bom funcionamento da máquina administrativa.

Se a advocacia do município estiver organizada em carreira, o que pressupõe investidura no cargo mediante prévia aprovação em concurso público, o procurador do município terá maior autonomia para emitir seus pareceres, aos quais - segundo o modelo ora proposto - o administrador público estaria vinculado. Assim, no extenso leque de opções que integram a discricionariedade administrativa, haveria o gestor público de se conter nos limites da legalidade. Trata-se de um domínio ético sobre a política, que permitiria, a um só tempo, o eficiente autocontrole da administração pública e o estabelecimento de parâmetros objetivos para a aplicação da norma do artigo 11 da Lei Federal no 8.429, de 2/6/1992.

\footnotetext{
${ }^{11}$ A propósito, Bobbio (1986) sustenta que o conceito de democracia direta tem de ser interpretado na linha de uma democracia participativa: "Não consta que Marx pensasse numa democracia direta [stricto sensu] quando via no exercício do poder por parte dos communards de Paris o germe de uma organização estatal diversa daquela do estado representativo (...). Hoje, se se quer apontar um índice do desenvolvimento democrático este não pode mais ser o número de pessoas que têm o direito de votar, mas o número de instâncias (diversas daquelas políticas) nas quais se exerce o direito de voto (...). Destarte - prossegue Bobbio -, "(...) deveremos procurar ver se aumentou não o número de eleitores, mas o espaço no qual o cidadão pode exercer seu próprio poder de eleitor. Podemos assim considerar como reforma democrática, nesta direção, a que instituiu os conselhos escolares (...)" (p. 43, 56).
} 


\section{CONSIDERAÇÕES FINAIS}

No encaminhamento das conclusões do presente trabalho, importante acentuar inicialmente, alterando um pouco a ordem da exposição que se fez até aqui, a importância da estatística como instrumento para a investigação empírica. Levantamentos feitos na Pnad Contínua de 2018, por exemplo, são indicadores sociais relevantes para que se possa estabelecer relações internas da amostra (representativa da realidade brasileira), estendendo as conclusões a toda a população.

Conquanto não fosse o propósito das investigações levadas a termo o tratamento mais detalhado dos dados das fontes oficiais - tanto assim que o presente estudo limitou-se ao exame do material de divulgação das pesquisas - buscando-se apenas sensibilizar o leitor para a premência de um adequado encaminhamento das questões sociais, certo é que os elementos coligidos apontam para as diversas possibilidades de intervenção emancipadora do Direito.

Deve-se à Sociologia crítica, tanto quanto às diversas linhas de interpretação crítica do Direito, o desvelamento dos pressupostos e implicações ideológicas do tratamento que ambos, abandonando o ideal da objetividade, dão aos fatos sociais, convencidos que estão sociólogos e juristas das limitações subjetivas do seu campo de pesquisa.

A desconfiança da razão, que se põe de uma perspectiva de superação do cientificismo, da metafísica social e jurídica, não pode levar, todavia, a ponto de renunciar a importância dos diversos paradigmas que se sucederam no curso da história do Direito e da Sociologia, intersecção que se fez presente nos trabalhos de Durkheim (1982), e, sobretudo, de Max Weber (1969), numa linha que convergiu mais tarde para o funcionalismo, como registra Talcott Parsons (1974).

Também a leitura marxista, que aponta para o condicionamento ideológico de todo conhecimento, exerceu um importante papel rumo à emancipação da ciência. Embora, todavia, seja possível sustentar que o ponto de vista da classe proletária é, em cada período histórico, superior ao das classes conservadoras, não se pode dizer que seria a classe revolucionária a única capaz de reconhecer e proclamar o processo de mudança social. Como observa Michael Löwy (1978), seria um grande equívoco admitir a infalibilidade, a priori, de toda ciência situada da perspectiva proletária e o erro absoluto e necessário de toda pesquisa fundada em outras bases, na linha de um reducionismo dogmático que ignora a autonomia relativa da produção científica em relação às classes sociais.

De fato, não se pode fazer uma interpretação economicista da visão que Marx e Engels (1965) tinham do Direito. Em muitas passagens do Prefácio da Contribuição à Crítica da Economia Política, lê-se que os elementos da superestrutura estão separados da base econômica. Neste exato sentido também a posição de Engels, na carta que escreveu a J. Bloch, datada de $21 / 22$ de setembro de 1890, nas cartas endereçadas a Conrad Schmidt (27/10/1890) e a Franz Mehring (14/7/1893).

O mérito do modelo funcionalista reside no entendimento de que, embora em dado momento histórico a ciência possa servir aos interesses da classe dominante, representada pelo Estado, nada impede que, de outra forma, também participe do processo de mudança social, visão epistemológica perfeitamente compatível, por exemplo, com a teoria dos paradigmas, formulada por Thomas Kuhn (1982).

Como se mencionou no início do presente trabalho, o modelo funcionalista, que busca explicar o funcionamento de um conjunto de variáveis, determinado a partir de suas compatibilidades e tensões, mecanismos de autorregulação e controle, afigura-se mais adequado ao entendimento do que ocorre nas sociedades complexas, em que a emergência crescente de conflitos passa a demandar a introdução, cada vez maior, de canais de institucionalização, um deles o Direito.

A produção do Direito, ao mesmo tempo que se faz dentro de relações de dominação burocrática e capitalista, não pode ser vista como puro arbítrio nem apenas como forma de legitimar o injusto pelo procedimento. Mesmo em autores como John Rawls e Jürgen Habermas, procedimentalistas, a denúncia da perversa situação de um Direito que se esgota na estrutura, de um Direito que olha os fins sem considerar os meios, aparece de maneira angustiante. Habermas (1980) defende que o Direito integra a esfera cultural, um compartimento do mundo vivido que está preservado da ameaça da esfera sistêmica, ao passo que Rawls (1981) sustenta que um Direito destituído de sentido não é Direito. 
Karl-Otto Apel (1994), que ocupa um lugar importante na ética do discurso, acentua a necessidade de uma interpretação normativa comprometida com valores, sem o que o Direito perde o sentido. Procedendo a uma crítica do reducionismo marxista, observa que é preciso estar atento à realidade de cada povo, de cada país. O proletariado da sociedade industrial ocidental é diferente do proletariado do Terceiro Mundo, que é miserável, sim, mas não "portador das forças de produção" (p. 155). Além disso, distintos são seus interesses materiais.

Apel conclui argumentando que o engajamento social deve ter em conta, na perspectiva de uma ética filosófica, cada situação concreta, na linha de uma interpretação histórico-evolutiva, orientada para a compreensão de fins normativamente situada. E se é certo que as tradicionais ciências humanistas do espírito são insuficientes como estratégia de emancipação, diante do ocultamento ideológico dos interesses materiais, certo também é que o entendimento disso revela-se importante para que se ponha as Ciências Sociais empírico-analíticas e normativo-analíticas a serviço da transformação social. Nesse contexto, Apel reabilita não apenas o marxismo (filiando-se àquele não ortodoxo, não dogmático-determinista, e sim ao humanista-emancipatório), mas também o funcionalismo como estratégia de emancipação duradoura.

Enfim, é defensável a possibilidade de estabelecer pretensões emancipatórias para os atores jurídicos, tudo dependendo do lado em que se pretende ficar no curso da História. Àqueles que buscam reduzir tudo à esfera do domínio da técnica, a um mundo da vida colonizado pelo agir estratégico, haverá sempre quem responda com um vestígio de humanidade, senão por questões racionais ou altruístas, sabedores de que chegará um tempo em que se cumprirá o vaticínio de Josué de Castro, feito em um dos congressos da Organização das Nações Unidas para a Alimentação e a Agricultura (FAO), objeto do registro lançado por Alceu Amoroso Lima no "Prefácio à décima edição" do livro de Josué de Castro, Geografia da Fome: "Enquanto metade da humanidade não come, a outra metade não dorme com medo de quem não come" (1992, p. 22). E os atores sociais, particularmente os atores jurídicos, não podem ficar indiferentes a isso.

\section{REFERÊNCIAS}

AMORIM, D.; NADER, V. Legião miserável do país supera a população belga. O Estado de São Paulo, Economia, 7 nov. 2019, p. B-6.

APEL, K. O. Estudos de moral moderna. Tradução Benno Dischinger. Petrópolis: Editora Vozes, 1994.

ARISTÓTELES. Obras (completas). Tradução Francisco P. Samaranch. Madrid: Tolle Lege Aguilar, 1967.

ASCENSÃO, J. de O. Alteração das circunstâncias e justiça contratual no novo Código Civil. In: Novos Direitos - após seis anos de vigência do Código Civil de 2002. Curitiba: Juruá Editora, 2009.

BOBBIO, N. El análisis funcional del derecho: tendencias y problemas. In: MIGUEL, A. R. Contribución a la teoría del derecho. Valencia: Fernando Torres Editor, 1980.

BOBBIO, N. O futuro da democracia - uma defesa das regras do jogo. 3. ed. Tradução Marco Aurélio Nogueira. Rio de Janeiro: Paz e Terra, 1986.

BRASIL. Constituição da República Federativa do Brasil de 1988. 1988. Disponível em: http://www.planalto.gov.br/ccivil_03/ constituicao/constituicaocompilado.htm. Acesso em: 23 ago. 2020.

BRASIL. Decreto no 4.956, de 9 de setembro de 1903. Disponível em: http://www.planalto.gov.br/ccivil_03/decreto/1900-1909/ D4956.htm. Acesso em: 23 ago. 2020.

BRASIL. Decreto-lei no 3.365, de 21 de junho de 1941. Disponível em: http://www.planalto.gov.br/ccivil_03/decreto-lei/ del3365.htm. Acesso em: 23 ago. 2020.

BRASIL. Decreto no 591, de 19 de maio de 1969. Disponível em: http://www.planalto.gov.br/ccivil_03/decreto/1990-1994/ d0591.htm. Acesso em: 23 ago. 2020.

BRASIL. Decreto Legislativo no 226, de 1991. Disponível em: https://www2.camara.leg.br/legin/fed/decleg/1991/decretolegislativo-226-12-dezembro-1991-358251-exposicaodemotivos-146136-pl.html. Acesso em: 23 ago. 2020.

BRASIL. Lei no 3071, de 1o de janeiro de 1916. Código Civil Brasileiro. Disponível em: http://www.planalto.gov.br/ccivil_03/leis/ L3071.htm. Acesso em: 23 ago. 2020.

BRASIL. Lei no 4.504, de 30 de novembro de 1964. Disponível em: http://www.planalto.gov.br/ccivil_03/leis/l4504.htm. Acesso em: 23 ago. 2020.

BRASIL. Lei no 4.717, de 29 de junho de 1965. Disponível em: http://www.planalto.gov.br/ccivil_03/leis//4717.htm. Acesso em: 23 ago. 2020. 
BRASIL. Lei no 6.194, de 19 de dezembro de 1974. Disponível em: http://www.planalto.gov.br/ccivil_03/leis/l6194.htm. Acesso em: 23 ago. 2020.

BRASIL. Lei no 7.347, de 24 de julho de 1985. Disponível em: http://www.planalto.gov.br/ccivil_03/leis//7347orig.htm. Acesso em: 23 ago. 2020.

BRASIL. Lei no 8.069, de 13 de julho de 1990a. Disponível em: http://www.planalto.gov.br/ccivil_03/leis/l8069.htm. Acesso em: 23 ago. 2020.

BRASIL. Lei no 8.078, de 11 de setembro de 1990b. Disponível em: http://www.planalto.gov.br/ccivil_03/leis//8078compilado. htm. Acesso em: 23 ago. 2020.

BRASIL. Lei no 8.429, de 2 de junho de 1992a. Disponível em: http://www.planalto.gov.br/ccivil_03/leis/l8429.htm. Acesso em: 23 ago. 2020.

BRASIL. Lei no 8.666, de 21 de junho de 1993. Disponível em: http://www.planalto.gov.br/ccivil_03/leis/I8666cons.htm. Acesso em: 23 ago. 2020.

BRASIL. Lei no 8.560, de 29 de dezembro de 1992b. Disponível em: http://www.planalto.gov.br/ccivil_03/leis/l8560.htm. Acesso em: 23 ago. 2020.

BRASIL. Lei no 8.989, de 24 de fevereiro de 1995a. Disponível em: http://www.planalto.gov.br/ccivil_03/leis/l8989.htm. Acesso em: 23 ago. 2020.

BRASIL. Lei no 9.099, de 26 de setembro de 1995b. Disponível em: http://www.planalto.gov.br/ccivil_03/leis/l9099.htm. Acesso em: 23 ago. 2020.

BRASIL. Lei no 9.784, de 29 de janeiro de 1999. Disponível em: http://www.planalto.gov.br/ccivil_03/leis/l9784.htm. Acesso em: 23 ago. 2020.

BRASIL. Lei no 10.257, de 10 de julho de 2001. Disponível em: http://www.planalto.gov.br/ccivil_03/LEIS/LEIS_2001/L10257. htm. Acesso em: 23 ago. 2020.

BRASIL. Lei no 10.406, de 10 de janeiro de 2002. Código Civil. Disponível em: http://www.planalto.gov.br/ccivil_03/leis/2002/ L10406compilada.htm. Acesso em: 23 ago. 2020.

BRASIL. Lei no 12.850, de 12 de agosto de 2013. Disponível em: http://www.planalto.gov.br/ccivil_03/_ato2011-2014/2013/ lei/l12850.htm. Acesso em: 23 ago. 2020.

BRASIL. Lei no 13.105, de 16 de março de 2015a. Código de Processo Civil. Disponível em: http://www.planalto.gov.br/ccivil_03/_ato2015-2018/2015/lei/l13105.htm. Acesso em: 23 ago. 2020.

BRASIL. Lei no 13.146, de 6 de julho de 2015b. Disponível em: http://www.planalto.gov.br/ccivil_03/_ato2015-2018/2015/lei/ I13146.htm. Acesso em: 23 ago. 2020.

BRASIL. Lei no 13.874, de 20 de setembro de 2019a. Disponível em: http://www.planalto.gov.br/ccivil_03/_ato2019-2022/2019/ lei/L13874.htm. Acesso em: 23 ago. 2020.

BRASIL. Lei complementar no 101, de 4 de maio de 2000. Disponível em: http://www.planalto.gov.br/ccivil_03/leis/lcp/lcp101. htm. Acesso em: 23 ago. 2020.

BRASIL. Medida provisória no 904, de 11 de novembro de 2019b. Disponível em: http://www.planalto.gov.br/ccivil_03/_ Ato2019-2022/2019/Mpv/mpv904.htm. Acesso em: 23 ago. 2020.

BRASIL. Tribunal de Justiça de São Paulo. Ap. Cív. no 0009241-55.2011.8.26.0602. 7ạ Câm. de Dir. Púb. Data de julgamento: 4 jun. 2012. Disponível em: https://tj-sp.jusbrasil.com.br/jurisprudencia/898861137/apelacao-civel-ac-92415520118260602-sp-0009241-5520118260602/inteiro-teor-898861157?ref=juris-tabs. Acesso em: 23 ago. 2020.

BRASIL. Tribunal de Justiça de São Paulo. Ap. Cív. no 1008486-95.2018.8.26.0625. 7ạ Câm. de Dir. Púb. Data de julgamento: 25 abr. 2019c. Disponível em: https://tj-sp.jusbrasil.com.br/jurisprudencia/890849685/apelacao-civel-ac-10084869520188260625-sp-1008486-9520188260625/inteiro-teor-890849784?ref=juris-tabs. Acesso em: 23 ago. 2020.

BRÉHIER, E. Historia de la filosofía. Tradução Juan Antonio Pérez Milán e María Dolores Morán. Madrid: Editorial Tecnos, 1988. Vol. 1.

CAPPELLETTI, M. Proceso, ideologías, sociedad. Tradução Santiago Sentís Melendo e Tomas A. Banzhaf. Buenos Aires: Ediciones Jurídicas Europa-América, 1974.

CARDOSO, F. H. Autoritarismo e democratização. Rio de Janeiro: Paz e Terra, 1975.

CROZIER, M. On ne change pas la societé par decret. Paris: Bernard-Grasset, 1979.

DUGUIT, L. Las transformaciones del derecho. Tradução Carlos G. Posada. Buenos Aires: Heliasta, 1975.

DUGUIT, L. Traité de droit constitutionnel. 3. ed. T. 1. Paris: Ancienne Librairie Fontemoing, 1927.

DURKHEIM, E. As regras do método sociológico. Tradução Maria Isaura Pereira de Queiroz. 10. ed. São Paulo: Editora Nacional, 1982.

FALETTO, E.; CARDOSO, F. H. Dependência e desenvolvimento da América Latina. Rio de Janeiro: Zahar, 1970. 
FARIAS, C. C. de. O calvário do § 2ㅇ do art. 1.276 do Código Civil: vida e morte de um malfadado dispositivo legal a partir de uma interpretação constitucional. In: CARVALHO NETO, I. de (org.). Novos direitos: após seis anos de vigência do Código Civil de 2002. Curitiba: Juruá Editora, 2009.

FOUCAULT, M. Microfísica do poder. Tradução Roberto Machado. 4. ed. Rio de Janeiro: Graal, 1979.

FRANCE, A. Crainquebille. New York: Dodd, Mead and Company, Inc., 1922.

FRIEDMAN, L.; LADINSKY, J. O direito como instrumento de mudança social incremental. In: FALCÃO, J.; SOUTO, C. (org.). Sociologia e direito. Tradução Maria Tereza Duarte Lima. São Paulo: Pioneira, 1980.

FRIEDMANN, W. El derecho en una sociedad en transformación. Tradução Florentino M. Torner. México: Fondo de Cultura Económica, 1966.

GRAVAS, D. Informalidade avança e reduz remuneração, O Estado de S. Paulo, 13 out. 2019, p. B-1.

HABERMAS, J. A crise de legitimação no capitalismo tardio. Tradução Vamireh Chacon. Rio de Janeiro: Tempo Brasileiro, 1980. IBGE. Censo 2010. Disponível em: https://censo2010.ibge.gov.br/. Acesso em: 23 ago. 2020.

KUHN, T. A estrutura das revoluções científicas. Tradução Nelson Boeira e Beatriz Vianna Boeira. São Paulo: Perspectiva, 1982. LEÃO XIII. Sobre a condição dos operários (Rerum Novarum). 3. ed. Petrópolis: Vozes, 1950.

LIMA, A. A. Prefácio à décima edição. In: CASTRO, J. de. Geografia da fome (o dilema brasileiro: pão ou aço). 11. ed. Rio de Janeiro: Gryphus, 1992.

LÖWY, M. Método dialético e teorias políticas. Rio de Janeiro: Editora Paz e Terra, 1978.

LUHMANN, N. Sociologia do direito. Tradução Gustavo Bayer. Rio de Janeiro: Tempo Brasileiro, 1983.

MANZINI, V. Trattato di diritto penale italiano. Torino: Unione Tipografico; Editrice Torinese, 1948. Vol. 1.

MARTINS, J. de S. Exclusão social e a nova desigualdade. 2. ed. São Paulo: Ed. Paulus, 1997.

MARX, K.; ENGELS, F. A ideologia alemã e outros escritos (primeira parte). Tradução Waltensir Dutra e Florestan Fernandes. Rio de Janeiro: Zahar Editores, 1965.

MARX, K.; ENGELS, F. Obras escolhidas. São Paulo: Alfa-Ômega, [1986?]. Vol. 3. (Tradução realizada com autorização da Instituição de Marxismo-Leninismo do Anexo ao Comitê Central da P.C.U.S.).

MONTORO, A. F. Introdução à ciência do direito. 20. ed. São Paulo: Ed. Revista dos Tribunais, 1991.

MOREIRA NETO, D. de F. Mutações do direito administrativo. 3. ed. Rio de Janeiro: Renovar, 2007.

NADER, V. Emprego informal recorde derruba produtividade da economia brasileira. O Estado de São Paulo, Economia, 16 nov. 2019, p. B-1.

NERY, P. F. Que tipo de país somos. O Estado de São Paulo, Economia, 26 nov. 2019a, p. B-5.

NERY, P. F. Uganda, aqui. O Estado de São Paulo, Economia, 29 out. 2019b, página B-4.

NEVES, A. C. Metodologia jurídica: problemas fundamentais. Coimbra: Coimbra Editora, 1993.

NINO, C. S. Introducción al análisis del derecho. 2. ed. Buenos Aires: Editorial Astrea, 1984.

O DRAMA de muitos jovens. O Estado de S. Paulo, Notas e Informações, 23 out. 2019, p. A-3.

OFFE, C. Capitalismo avançado e o welfare state. In: CARDOSO, F. H.; MARTINS, C. E. (org.). Política e sociedade. São Paulo: Nacional, 1981.

ONU. Organização das Nações Unidas. Declaração Universal dos Direitos Humanos. 1948. Disponível em: https://nacoesunidas.org/direitoshumanos/declaracao/. Acesso em: 23 ago. 2020.

ORTEGA Y GASSET, J. Obras completas. T. 1. Madrid: Alianza Editorial, 1983.

PARSONS, T. Los cambios sociales. Tradução Amitai e Eva Etzioni. México: Fondo de Cultura Económica, 1974.

PLATÃO. Obras (completas). Tradução Maria Araújo et al. Madrid: Tolle Lege Aguilar, 1969.

RAWLS, J. Uma teoria da justiça. Tradução Vamireh Chacon. Brasília: Ed. da UnB, 1981.

ROUSSEAU, J. J. A origem da desigualdade entre os homens. Tradução Eduardo Brandão. São Paulo: Pinguim \& Cia das Letras, 2017.

RUIVO, F. Aparelho judicial, Estado e legitimação. In: FARIA, J. E. (org.). Direito e justiça: a função social do judiciário. São Paulo: Ed. Ática, 1989.

SANTOS, W. G. dos. Do laissez-faire à cidadania de recesso. In: ARAÚJO, R. B. de (org.). Cidadania e justiça. Rio de Janeiro: Campus, 1978.

SÃO PAULO. Constituição Estadual. 1989. Disponível em: https://www.al.sp.gov.br/repositorio/legislacao/constituicao/1989/ compilacao-constituicao-0-05.10.1989.html. Acesso em: 23 ago. 2020.

SÃO PAULO. Decreto no 45.490, de 30 de novembro de 2000. Disponível em: https://www.al.sp.gov.br/repositorio/legislacao/ decreto/2000/decreto-45490-30.11.2000.html. Acesso em: 23 ago. 2020. 
SÃO PAULO. Decreto no 58.897, de 20 de fevereiro de 2013. Disponível em: https://www.al.sp.gov.br/repositorio/legislacao/ decreto/2013/decreto-58897-20.02.2013.html. Acesso em: 23 ago. 2020.

SÃO PAULO. Lei no 13.296, de 23 de dezembro de 2008. Disponível em: https://www.al.sp.gov.br/repositorio/legislacao/ lei/2008/lei-13296-23.12.2008.html. Acesso em: 23 ago. 2020.

SÃO PAULO. Lei no 16.498, de 18 de julho de 2017. Disponível em: https://www.al.sp.gov.br/repositorio/legislacao/lei/2017/ lei-16498-18.07.2017.html. Acesso em: 23 ago. 2020.

SCHWARTZMAN, S. Bases do autoritarismo brasileiro. 2. ed. Brasília: Campus, 1982.

TCE aponta R\$ 49,5 bi em mais de 1.500 obras paralisadas e atrasadas no Estado de SP, TCESP, 5 out. de 2019. Disponível em: https://www.tce.sp.gov.br/6524-tce-aponta-r-495-bi-mais-1500-obras-paralisadas-e-atrasadas-estado-sp. Acesso em 23 ago. 2020.

TRUBEK, D. Para uma teoria social do direito: ensaio sobre direito e desenvolvimento. In: FALCÃO, J.; SOUTO, C. (org.). Sociologia e direito. Tradução Ciro e Sue Menescal. São Paulo: Pioneira, 1980.

WEBER, M. Economía y sociedad, esbozo de sociología comprensiva. Tradução José Medina Echavarría et al. México: Fondo de Cultura Económica, 1969.

ZAFFARONI, E. R. Tratado de Derecho Penal. Buenos Aires: Ediar - Sociedad Anónima Editora Comercial, Industrial y Financiera, 1981. Vol. 3. 